\title{
グリーンシートの粉体充填率とバインダ量が アルミナ基板の寸法精度，反りに及ぼす影響*
}

\author{
上山守**，山本孝***，岡崎 清
}

Tamotsu Ueyama, Takashi Yamamoto and Kiyoshi Okazaki: Influence of Packing Density and Binder Contents of the Green Sheet on the Dimensional Stability and Warping of the Sintered Alumina Substrates.

The relations among packing density in $\mathrm{Al}_{2} \mathrm{O}_{3}$ green sheet and shrinkage, demensional stability and warping were discussed theoretically and experimentally. Dimensional stability in $\mathrm{Al}_{2} \mathrm{O}_{3}$ substrate strongly depended on packing density of particles in the green sheet and was experimentally varied by $0.5 \%$ when the packing density was changed around 1 vol\%. These experimental values were fairly agreed with those obtained by theoretical considerations. Moreover, it was found that the warping observed in the sintered substrate was caused by the difference of shrinkage in thickness direction, which was due to the variations of packing density and binder content in thickness direction. This variation could be controlled around zero using the green sheet with a packing density of above $60 \mathrm{vol} \%$. We could get the $\mathrm{Al}_{2} \mathrm{O}_{3}$ substrate with high dimensional stability.

(Received March 14, 1989)

\section{I 緒言}

アルミナ基板の大型化，高精度化が急速に進んでいる。 厚膜ハイブリッド IC やパッケージの製造自動化に不可 欠なためである。これまでのアルミナ基板 $(50 \times 50 \mathrm{~mm})$ では, 寸法精度は士0.8\%程度, 反りは $0.2 \mathrm{~mm} / 25 \mathrm{~mm}$ 以下であっだ.一方，これに比べて大型，高精度アルミ ナ基板 $(100 \times 100 \mathrm{~mm}$ 以上) の場合，寸法精度は土0.3\% 以下, 反りは $0.1 \mathrm{~mm} / 25 \mathrm{~mm}$ 以下のものが要求されて いる，良く知られているように，アルミナ基板は，以下 の手順で作られる. 原料は $\alpha$ アルミナとフラックス（焼 結助放) である，てれに結合剂として有機樹脂（バイン ダと呼ふ）及び溶剂を混合してスラリとし，ドクターブ レード法でグリーンシートに成形する る ${ }^{2 \sim 4)}$. セラミック スでは，未焼結セラミックシートを，一般にグリーン シートと呼称する.アルミナ基板はこのグリーンシー ト芜焼成して作る。焼成条件は，焼成温度； $1500^{\circ} \mathrm{C} \sim$ $1600^{\circ} \mathrm{C}$, 焼成時間; 数特間である. グリーンシートは上 記の焼成条件で，通常で活40〜50\%の体積収縮を生じそ れにともない反りが発生する，体積収縮量はグリーン シートの粉体充填率上密接に関係していると考えられ る5,6). しかし，実際には大きな変動がみられる。また 等方収縮しない場合が多い. 反りが小さい，高寸法精度 基板を再現性良く製造するには，熎成収縮摔や反りに及 ば9グリーンシートの粉体充填率の影響を系統的, 定量
的に検討する必要がある。また，とのためには，グリー ンシートの粉体充媜率の制御技術の確立が必要である. 本報ではグリーンシートのX方向とY方向及びZ方向の 焼成線収縮率について，理論的実験的に検討した，X力 向はグリーンシートの横方向のてとであり，ドクターブ レードの幅方向に対応する．Y方向はグリーンシートの 縦方向すなわちシート成形時の流れ方向である. また， Z方向はグリーンシートの厚さ方向である.てれら， 3 方向の焼成線収縮率をむとに，基板の反りを制御する方 法を提案した。

\section{II 実 験 方 法}

\section{I-1 グリーンシートの作成}

実験に使用した $\alpha$ アルミナ，フラックス及びバイン ダは Table 1 に示した. $\alpha$ アルミナは, 純度; 99.5\%以 上, 平均粒径； $1.1 \mu \mathrm{m}$ の粉碎アルミナ（昭和電工）であ る.フラックスの重量組成は, $\mathrm{Al}_{2} \mathrm{O}_{3} ; 6.1 \%, \mathrm{SiO}_{2} ; 61.9$ $\%, \mathrm{MgO} ; 28.6 \%, \mathrm{CaO} ; 3.4 \%$ である.上記組成の粉体 を焼成温度； $1550^{\circ} \mathrm{C}$ で溶融，ガラス化し，水砕後ボール ミルで微粉砕した、粉砕は，比表面積が各々 1.0，20，

* 平成元年 3 月14日受理.

** 相模工業大学, $=251$ 藤沢市辻堂西海岸1-1-25（三菱鉱業 セメント(维セラミックス研究所併任，埼玉県秩父郡横瀬朾 2270).

****防衛大学校, 干239 横須賀市走水1-10-20.

†相模工業大学, T251 藤沢市过堂西海岸1-1-25. 
Table 1 Raw materials and composition of slurry.

\begin{tabular}{|c|c|c|c|}
\hline & Materials & \multicolumn{2}{|c|}{ Composition (wt Part) } \\
\hline Alumina & $\begin{array}{l}*_{\mathrm{AL}-45^{\mathrm{R}}} \\
\text { purity } 99.5 \mathrm{wt} \not 6\end{array}$ & & 96 \\
\hline Glass flux & $\begin{array}{lr}\mathrm{Al}_{2} \mathrm{O}_{3} & 6.1 \mathrm{wt} \not 6 \\
\mathrm{SiO}_{2} & 61.9 \\
\mathrm{MgO} & 28.6 \\
\mathrm{CaO} & 3.4\end{array}$ & & 4 \\
\hline Binder & Poly vinyl butyral & & $2-20$ \\
\hline Plasticizer & Butyl benzil phthalate & & $1-10$ \\
\hline Mixed solvent & $\begin{array}{l}\text { Trichloro ethylene } \\
\text { Tetra chloro ethylene } \\
\text { n-Butanol }\end{array}$ & $\left.\begin{array}{l}60 \mathrm{wt} \not \\
23 " \prime \\
17 " \prime\end{array}\right)$ & 55 \\
\hline
\end{tabular}

*Showa denko Co. Ltd.

100，200及び $364 \mathrm{~m}^{2} / \mathrm{g}$ になるように制御した。 バイン ダはポリビニルブチラール（皘水化学製，タイプ BL -2 ), 可塑剤はブチルベンジルフタレート（大八化学製） を用いた。 スラリはボールミルで湿合した．アルミナ， ガラスフラックス, バインダ, 可塑剤及び溶剂をボール ミルポットに採取し，解粒分散湿合法で湿合した．混合

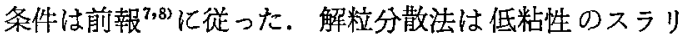
中で凝集粒子を一次柆子に解粒する第 1 段階と，シート 成形に必要なバインダ及び可塑剂を追加し均一に分散さ せる第 2 段階で構成される. 第 2 段階でバインダと可塑 滖を追加するのは，グリーンシートに成形性とハンドリ ング性を賦与するためである．本混合法を解粒分散スラ リ混合法と命名した ${ }^{7,8}$. グリーンシートは，Fig. 1 の 製造工程に従い, 幅: $500 \mathrm{~mm}$, 厚さ；0.6 mm Kドクタ ーブレード法で成形した。成形条件は，ブレードギャッ プ; $1.8 \mathrm{~mm}$, 成形速度; $100 \mathrm{~mm} /$ 分, 乾燥は常温及び加 熱乾燥の 2 条件とした.

\section{II -2 焼成方法}

基板は連続焼成式トンネル電気炉で焼成した，焼成は 以下の手順で行った，先ず，グリーンシートを $34.73 \times$ $42.26 \mathrm{~mm}$ の寸法に金型で打抜いて焼成試料とした. と の試料を $250^{\circ} \mathrm{C}$ の大気中で 2 時間焼成して脱樹脂した. 次に，昇温速度； $6^{\circ} \mathrm{C} /$ 分で $300^{\circ} \mathrm{C}$ まで昇温し 1 時間保 持した。 この段階で，ほとんどのバインダは除去された。

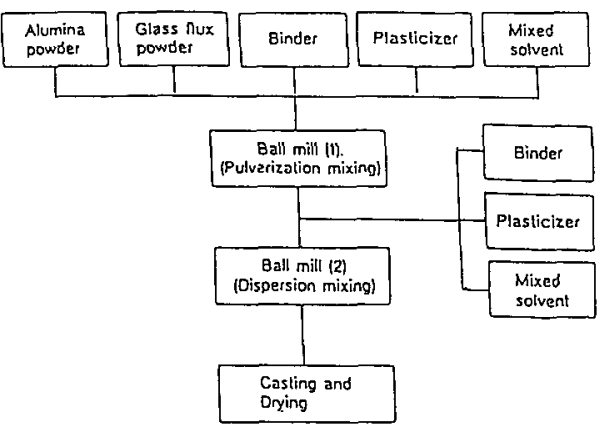

Fig. 1 Flow diagram of the slurry and green sheet production process.
更に，昇温速度； $15^{\circ} \mathrm{C} /$ 分で $1200^{\circ} \mathrm{C}$ まで昇温して，残 存するバインダ分解残渣をほぼ完全に除去した，その後， 昇温速度を $4.4^{\circ} \mathrm{C} /$ 分 亿変更して, $1550^{\circ} \mathrm{C}$ まで昇温し， 1 時間保持して焼結させた。. 冷却は炕内冷却（冷却速度 ; $7^{\circ} \mathrm{C} /$ 分) とした.

II -3 評洒方法

(1) 粉体充垻率

グリーンシートの粉体充填率は，以下の手順で計算し た.グリーンシートを金型で打抜き，その重量 $\left(\mathrm{W}_{1}\right)$ を 測定した. 更にこの試料の水中重量 $\left(\mathrm{W}_{2}\right)$ を測定し, 試料 の体積 $\left(\mathrm{V}_{1}\right)$ を, $\mathrm{V}_{1}=\left(\mathrm{W}_{1}-\mathrm{W}_{2}\right) \times$ (水の密度)上り求めた。 次に，800 $\mathrm{C}$ で 1 時間焼成してバインダと可塑剤を除去 し，この重量 ( $\mathrm{W}_{3} ;$ アルミナとガラスフラックスの重量 の和）を測定した。アルミナとガラスフラックスの真密 度（3.97と2.68）はアルキメデス法で測定した. 以上よ りグリーンシート中のアルミナとガラスフラックスの 体積 $\mathrm{V}_{2}=\left(0.96 \times \mathrm{W}_{3}\right) / 3.97$ 及び $\mathrm{V}_{3}=\left(0.04 \times \mathrm{W}_{3}\right) / 2.68$ を求め，(1)式加ら粉体充填率を計算した。

$$
\begin{aligned}
\text { 粉体充垻率 }= & \left(\mathrm{V}_{2}+\mathrm{V}_{3}\right) / \mathrm{V}_{1} \\
= & {\left[\left\{\left(0.96 \times \mathrm{W}_{3}\right) / 3.97\right\}+\right.} \\
& \left.\left\{\left(0.04 \times \mathrm{W}_{3}\right) / 2.68\right\}\right] / \mathrm{V}_{1}
\end{aligned}
$$

(2) グリーンシートのバインダ，可塑剤の含有量 グリーンシートに含まれるバインダと可塑剂の総含有 量 $\left(\mathrm{W}_{4}\right)$ は以下の方法で算出した．まずグリーンシート の重量 $\left(\mathrm{W}_{1}\right)$ 及び $800^{\circ} \mathrm{C}$ で 1 時間焼成した後の重量 $\left(\mathrm{W}_{3}\right)$ を測定し, 重量差 $\left(\mathrm{W}_{1}-\mathrm{W}_{3}\right)$ より計算した。

(3) ガラスフラックスの組成分析

グリーンシートに含有されるガラスフラックスの組成 㹥螢光X線分析法（理学電機，モデル $3063 \mathrm{M}$ ) で定量 分析した. フラックス中の $\mathrm{SiO}_{2}, \mathrm{MgO}$ 及び $\mathrm{CaO}$ は組成 比が既知の試料で検量線を作成し，比較定量した。

(4) 粒度分布之平均粒径

アルミナとガラスフラックスの粒度分布はミクロフオ 一トサイザ（セイシン企業，モデル SKN-500）で測定 した，平均粒径は粒度累皘分布曲線の $50 \%$ 値とした。

（5）比表面栍

アルミナとガラスフラックスの比表面皘は BET 法比 表面積自動測定装置（島津製作所，モデル2200）で測定 した.

\section{（6）焼成収縮率}

焼成収縮率は(2)式より計算した。試料は $34.73 \times 42.26$ $\mathrm{mm}$ の大きさにグリーンシートを金型で打抜いた．(2)式 の $\mathrm{L}_{1}$ と $\mathrm{L}_{2}$ は測定試料10個の焼成前後の長辺方向の長 さの平均值である.

$$
\text { 焼成収縮率 }(\%)=\left\{\left(\mathrm{L}_{1}-\mathrm{L}_{2}\right) / \mathrm{L}_{1}\right\} \times 100
$$

(7) 反り

反りは以下の手順で测定した．まず焼成基板を 2 枚の 定盤ではさんだ時の定盤間の間隔 $\left(\mathrm{t}_{1}\right)$ と焼成基板の厚さ 
$\left(\mathrm{t}_{2}\right)$ を測定し， $\left(\mathrm{t}_{1}-\mathrm{t}_{2}\right)$ を求め単位長さあたりに換算した. 反りの方向は,グリーンシートのキャリヤフィルム（マ イラフィルム) と接していた面（フィルム面之略称）が 内側に反る場合をプラス反り，フィルム面の反対側（ブ レード面と略称) が内側に反る場合をマイナス反りと定 義した.

\section{III 実験結果及び考察}

\section{III-1 粉体充填率之焼成収縮率}

グリーンシートの数体充垻率之燒成収縮率の関係及び 焼成収縮率の異方性を検討した，䡒成收縮率の異方性は グリーンシートのX方向とY方向及び Z 方向の䡒成線収 縮率の違いをいう．アルミナやチタン酸バリウムの場合 グリーンシートの粉体充買率は凝集粒子が減少すると粉 径に関係なく增加する7、凝集粒子加解粒される之粉体 充填率は $60.4 \mathrm{vol} \%$ 亿収斂する ${ }^{8,92}$. この飽和值は 8 配位 配列（単一斜列配位）した同大球の粉体充填率 60.45 vol\% と良く一致した ${ }^{10}$. 乙れは粉体が安定な充填状態 （普通 8 配位配列の充填は同大球を無圧成形すると得ら れる最大充填状態である。）にあるととを示唆している. グリーンシートの粉体充埧率が 60.4 vol\% の場合, 残り の 39. 6vol\% は，バインダと可塑剂及び気孔で占められ る. 上記の状態は，グリーンシートが焼結した時に生じ る体積収縮率が 39.6 vol\% になることである.この場合， グリーンシートの X, Y, Z 方向の焼成收綰率を $\alpha_{\mathrm{x}}, \alpha_{\mathrm{y}}$ $\alpha_{z}$ とすると，粉体充填率は次式で表される.

$$
\text { 粉体充填率 }=\left(1-\alpha_{\mathrm{x}}\right) \times\left(1-\alpha_{\mathrm{y}}\right) \times\left(1-\alpha_{z}\right)
$$

焼成線収綰率は体積收縮が等方性であれば次式に変換さ れる。

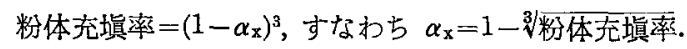
従って粉体充填率が 60.4 vol\% の場合は，乙の值佉約 15.5\%になる. 前述の経過を系統的に検討するため, 粉 体充冝率之㜔成収縮率の関係の理論式を求めた。 I-3(2) で記述したように，体積が $V_{1}$ のグリーンシート中の粉 体の総重量を $\mathrm{W}_{3}$ とすると粉体が占めるみかけの密度 $\left(\rho_{3}\right)$ は(3)式で示される。

$$
\rho_{3}=W_{3} / V_{1}
$$

体積が $\mathrm{V}_{1}$ の基板の重量をWとすると, 基板の理論密 度 $(\rho)$ は(4)式で示される。

$$
\rho=W / V_{1}
$$

粉体充填率は (3)，(4)式より(5)式で表される.

$$
\begin{aligned}
\rho_{3} / \rho & =\left(\mathrm{W}_{3} / \mathrm{V}_{1}\right) /\left(\mathrm{W} / \mathrm{V}_{1}\right) \\
& =\mathrm{W}_{3} / \mathrm{W}
\end{aligned}
$$

グリーンシートを焼成した時のX， $\mathrm{Y} ， \mathrm{Z}$ 方向の焼成 線収縮率を $\alpha_{\mathrm{x}}, \alpha_{\mathrm{y}}, \alpha_{z}$ とすると, 基板の焼結密度 $\left(\rho_{\mathrm{f}}\right)$ は(6)式で求められる.

$$
\rho_{\mathrm{f}}=\rho_{3} /\left\{\left(1-\alpha_{\mathrm{x}}\right) \times\left(1-\alpha_{\mathrm{y}}\right) \times\left(1-\alpha_{z}\right)\right\}
$$

$\rho_{\mathrm{f}}$ と $\rho$ の比 $\left(\rho_{\mathrm{f}} / \rho\right)$ をとすると $\gamma$ と(5)，(6)式加ら
(7)式で表される.

$$
\begin{aligned}
\gamma & =\rho_{3} /\left\{\rho \times\left(1-\alpha_{\mathrm{x}}\right) \times\left(1-\alpha_{\mathrm{y}}\right) \times\left(1-\alpha_{z}\right)\right\} \\
& =\left(\rho_{3} / \rho\right) /\left\{\left(1-\alpha_{\mathrm{x}}\right) \times\left(1-\alpha_{\mathrm{y}}\right) \times\left(1-\alpha_{z}\right)\right\}
\end{aligned}
$$

但し, $\rho_{3} / \rho$ は粉体充填率汇相当する.

ここでx方向と $\mathrm{Y}$ 方向の焼成線収縮率比 $\left(\alpha_{\mathrm{x}} / \alpha_{\mathrm{y}}\right)$ を $\beta, \mathrm{X}$ 方向と $\mathrm{Z}$ 方向の比 $\left(\alpha_{\mathrm{x}} / \alpha_{z}\right)$ を $\delta$ 之定義すると，(7) 式は(8)式で与えられる.

$$
\begin{aligned}
& \gamma=\left(\rho_{3} / \rho\right) /\left\{\left(1-\alpha_{\mathrm{x}}\right) \times\left(1-\alpha_{\mathrm{x}} / \beta\right) \times\left(1-\alpha_{\mathrm{x}} / \delta\right)\right\} \\
& \rho_{3} / \rho=\gamma \times\left(1-\alpha_{\mathrm{x}}\right) \times\left(1-\alpha_{\mathrm{x}} / \beta\right) \times\left(1-\alpha_{\mathrm{x}} / \delta\right)
\end{aligned}
$$

従って，X力向之 Z方向の焼成線収縮率比 $(\delta)$ は，

$$
\delta=\alpha_{\mathrm{x}} /\left\{1-\left(\rho_{3} / \rho\right) / \gamma \times\left(1-\alpha_{\mathrm{x}}\right) \times\left(1-\alpha_{\mathrm{x}} / \beta\right)\right\}
$$

ここでX力向とY方向の焼成線収紡率が等しければ, (9)式は(10)式に変更される.

$$
\delta=\alpha_{\mathrm{x}} /\left\{1-\left(\rho_{3} / \rho\right) / \gamma \times\left(1-\alpha_{\mathrm{x}}\right)^{2}\right\}
$$

Fig. 2 は(9)式より, 計算で求めた焼成線収縮率と $\delta$ の関係である. Fig. 2 の実線は, $\rho_{3} / \rho$ を0.604とし， $\gamma$ を 0.95 1.0の間で変化させた時のX方向の焼成線収縮率

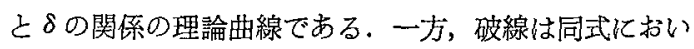
て $\gamma$ を 0.97 とし, $\rho_{3} / \rho$ を $0.604,0.59,0.58,0.57$ と 変化させた時の理論曲線である. Fig. 3 は，(8)式より 計算したX方向の焼成線収縮率と $\rho_{3} / \rho$ (粉体充填率) の 関係曲線である.Fig. 3 の実線は, $\beta=1$ (X方向とY方向 が等方収緶), $\gamma=1$ とし $\delta$ を. 85 1.2の間で変化させた 場合の計算で求められた関係曲線である. 破線は， $\beta=$ $0.99(\beta=0.99$ は Fig. 4 より計算で求めたX方向と $\mathrm{Y}$ 方

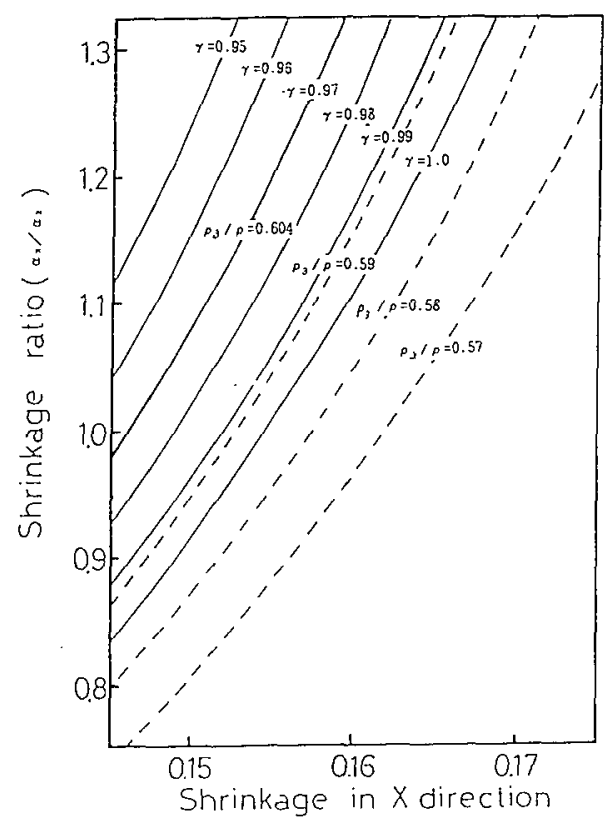

Fig. 2 Theoretical curves of shrinkage ratio vs shrinkage in $\mathrm{x}$ direction, $\delta=\alpha_{\mathrm{x}} /\left(1-\left(\left(\rho_{3} / \rho\right) / r\left(1-\alpha_{\mathrm{x}}\right)^{2}\right)\right)$ solid lines: $\gamma=0.95$ to $1.0, \rho_{3} / \rho=0.604$ broken lines: $\rho_{3} / \rho=0.604$ to $0.57, \gamma=0.97$. 


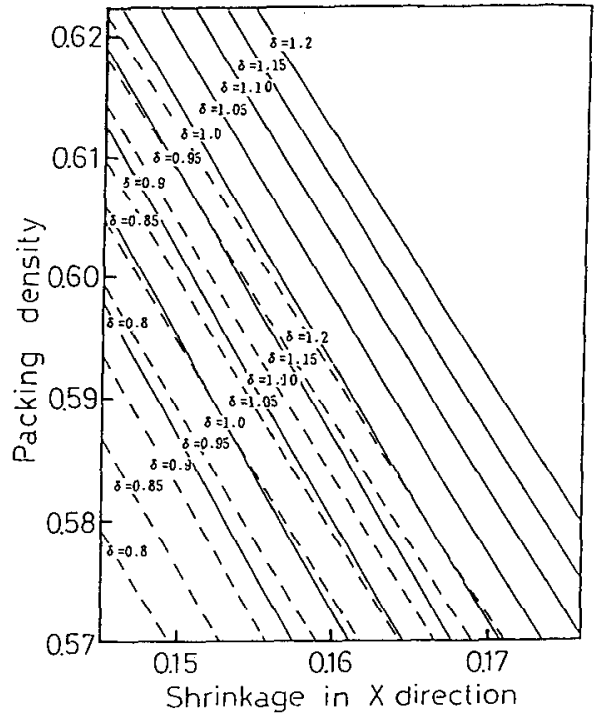

Fig. 3 Theoretical curves of packing density vs shrinkage in $x$ direction, $\left(\rho_{3} / \rho\right)=\gamma\left(1-\alpha_{x}\right)\left(1-\alpha_{x} / \beta\right)\left(1-\alpha_{x} / \delta\right)$. solid lines: $\delta=1.2$ to $0.8, \gamma=1, \beta=1$.

broken lines: $\delta=1.2$ to $0.8, \beta=0.99, \gamma=0.97$.

向の焼成収縮率比 $\left(\alpha_{x} / \alpha_{y}\right)$ の実測值に対応する. $), \gamma=$ $0.97(\gamma=0.97$ は96\%アルミナ基板（理論密度 3.91）の 実測密度比 0.967 (実測燒結密度 3.78) 0.972（実測焼 結密度 3.80）に対応する.）の場合について，同様に計 算により求めた関係曲線である. Fig. 4 は，X方向とY 方向の焼成線収縮率の実測值を, 粉体充填率に対してプ ロットした結果である．燒成収縮率の異方性が，燒結の 進行にとむない変化しないと仮定した場合, Fig. 3 及び4 より，X方向上Y方向の焼成線収縮率比 $(\beta)$ は，0.99で ある. また，X方向とZ方向の燒成線収縮率比 $(\delta)$ は， $\gamma$ が0.97の場合には，1.15である. 即ち，X方向の焼成線 収縮率は， $\mathrm{Z}$ 方向と比較して 1.15倍大きい，x方向の

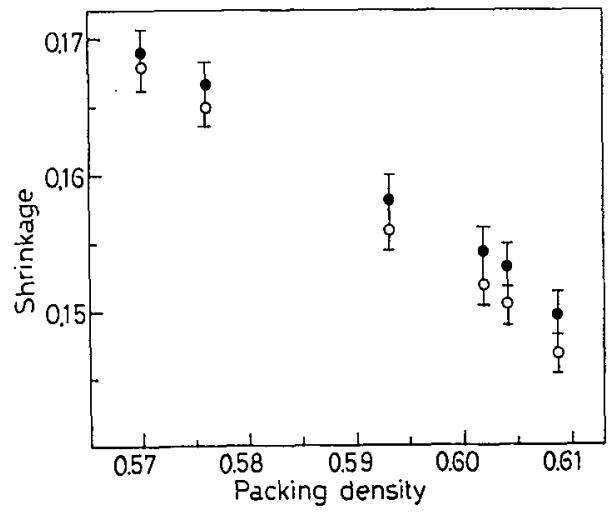

Fig. 4 Experimental values of shrinkage in $\mathrm{x}$ and $\mathrm{y}$ directions vs packing density. white circles: shrinkage in $\mathbf{x}$ direction black circles: shrinkage in y direction.
焼成線収縮率がY方向より小さく，且つZ方向の焼成線 収縮率がX，Y方向よりあ小さくなったのは，以下のよ うに考えると説明できる。ドクターブレード成形の場合， グリーンシートは先端部及び両端部から乾燥が始まり， 外形枠を形成する. この場合, 外形杂はX及びY方向の 乾燥収縮を妨害する．従ってX方向の粉体充埧率はY方 向に比べて高くなる，一方スラリ中の粉体粒子（アルミ ナとガラスフラックス）は乾燥収絔に際して，キャリヤ フィルムとの間で摩擦応力が生じる. この応力は, 乾燥 に上あなうX及びY方向での粉体粒子の移動を妨害する。 一方, $\mathrm{Z}$ 方向ではこの応力は生じない，従って Z 方向で は粉体は繳密に充填する. しかし，X，Y方向では緻密 化加進まない，乙のためX，Y方向の粉体の粉体克填率 は，Z方向に比へて低くなる．乙れらの結果として， $\mathrm{X}$ 方向の烧成収縮率が $\mathrm{Y}$ 方向より小さくなり， $\mathrm{Z}$ 方向は $\mathrm{X}$, Y方向より小さくなったあのと考元られる。焼結密度及

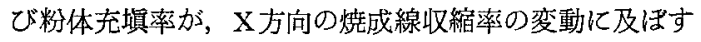
影響は Fig. 2 上り読み出せる. すなわち $3 \%$ \% の変 化は，1\%の変動をむたらし 2 vol\% の粉体充填率の変 動は，0.9\%の変動を生じさせる．ところで，一般にア ルミナ基板を焼成する場合, 以下の理由により焼結密度 は，普通，1\%前後の変動がある. 即ちよく知られてい るように，従来の燒成炋は，性能，構造などの原因によ り，炉内温度が炉内位置で，また時間的にかなり大きく 変動する，また，原料によって6，粉体の粒径，比表面 積が变動するために䡒結性が変わり, 焼結密度が変動す る. 従って，てれらを配虑すると，焼結基板の寸法精度 を $\pm 0.3 \%$ 以下に制御するためには，粉体充填率はすく なくとす $\pm 0.3 \mathrm{vol} \%$ 以下で制御するととが必要である.

III-2 粉体充填率と焼結基板の反り

グリーンシートを焼成する時に発生する，焼結基板の 反りは，原料粉（アルミナ, フラックス）の粉体物性や グリーンシートの特性に影響されると考えられている。 本項では，粉体充塓率と反りの関係を検討した。粉体充 填率が異なる 2 種類のグリーンシートは，フラックスの 比表面積を変えるととにより製造した. Fig. 5 は, 粉体

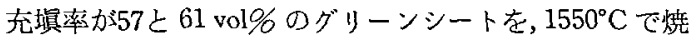
成した時の， $\mathrm{x}$ 方向の反りの形状を示した，粉体充填率 が 61 vol\% のグリーンシートは，比表面積 が $20 \mathrm{~m}^{2} / \mathrm{g}$ のガラスフラックスを用いて作成した. また, 57 vol\% グリーンシートは, 比表面積が $364 \mathrm{~m}^{2} / \mathrm{g}$ のガラスフラ ックスを用いて作成した．アルミナ含有量は $96 \%$ あ゙ある. 反りは，いずれも基板の端部はど大きくなった。またフ ィルム面を巻き込む方向に発生した．この反りは，ブレ 一ド面を下にして焼成すると，上にして焼成した場合 の1/2 以下になった，粉体充填率が高いダリーンシート （比表面積が $20 \mathrm{~m}^{2} / \mathrm{g}$ のガラスフラックスを使用）の場合, 反りは $0.03 \mathrm{~mm} / \mathrm{cm}$ であった。基板の反りは,グリーン 


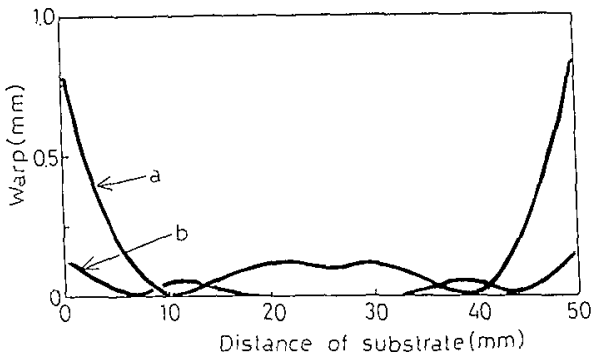

Fig. 5 Profiles of warp in $x$ direction of $\mathrm{Al}_{2} \mathrm{O}_{3}$ substrate sintered at $1550^{\circ} \mathrm{C}$ using two kinds green sheet with different packing density.

arrow a: green sheet with a packing density of 57 vol\%

arrow $b$ : green sheet with a packing density of 61 volg

シートのフィルム面とブレード面の焼成収縮率差により 発生すると考えられる，そこて，焼成収縮率差が生じる 原因を確かめ，上記の実験結舁を説明するため，以下の 検討を行った．まず第一にグリーンシートの厚み方向の 粒度分布及び組成の影響を検討した。しれらが燒成収縮 率差をひき扟こす原因になると考えられたためである。 具体的には以下の実験を行った.グリーンシートのフィ ルム面とブレード面を，各々，200 $\mu \mathrm{m}$ 万つ削り，ての切 削粉を $800^{\circ} \mathrm{C}$ で 1 時間焼成して烧成粉とした. $800^{\circ} \mathrm{C} の$ 焼成は，バインダと可塑剤を完全に除去することにある。 Fig. 6 は焼成粉の粒度分布, Table 2 は組成の定量分析結 果である．粒度分布及びフラックスの組成比は，フィル ム面，ブレード面とも配合原料と同一であった，上記の 実験を行った理由はアルミナやガラスフラックスには粗 大粒子や微粉が含まれているので，沈降したり，浮き上 がったりして厚み方向で粒度分布や組成に偏りを生じる

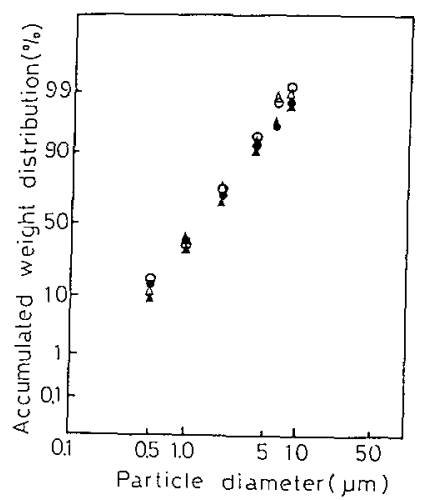

Fig. 6 Particle size distribution in the film and blade layers. white and black circles: particles in the blade and film side layers, respectively, $\mathrm{SPA}=364 \mathrm{~m}^{2} / \mathrm{g}$ white and black triangles: particles in the blade and film-side layers, respectively, $\mathrm{SPA}=20 \mathrm{~m}^{2} / \mathrm{g}, \mathrm{SPA}=$ specific surface area.
Table 2 Comparison of composition in starting materials, film and blade sides layers after sintering.

\begin{tabular}{l|c|c|c}
\hline & $\begin{array}{l}\text { Starting } \\
\text { composition }\end{array}$ & $\begin{array}{l}\text { Film side } \\
\text { layer }\end{array}$ & $\begin{array}{l}\text { Blade side } \\
\text { layer }\end{array}$ \\
\hline $\mathrm{Al}_{2} \mathrm{O}_{3}$ & 96.06 & 96.05 & 96.06 \\
$\mathrm{SiO}_{2}$ & 2.54 & 2.55 & 2.54 \\
$\mathrm{MgO}$ & 1.20 & 1.20 & 1.20 \\
$\mathrm{CaO}$ & 0.20 & 0.20 & 0.20 \\
\hline
\end{tabular}

ことが予想されたためである，以上の結果より，反りの 発生がグリーンシートの厚み方向の粒度分布や組成の偏 りによるものではないととがわかった。 そてで，反りの 発生のもう一つの原因と考えられるグリーンシートの内 部応力について検討した. Fig.7 は, 常温乾燥及び加熱 乾燥 $\left(120^{\circ} \mathrm{C}\right)$ したグリーンシートを, $1550^{\circ} \mathrm{C}$ で燒成した 時の基板の反りの測定結果である.グリーンシートはフ ィルム面を上にして焼成した．常温乾燥したグリーンシ 一トの反りは, シート中央部の場合, ガラスフラックス が $20 \mathrm{~m}^{2} / \mathrm{g}$ では $0.05 \mathrm{~mm} / \mathrm{cm}, 364 \mathrm{~m}^{2} / \mathrm{g}$ では $0.11 \mathrm{~mm} /$ $\mathrm{cm}$ であった。一方，加熱乾燥したグリーンシートでは， 各々 $0.01 \mathrm{~mm} / \mathrm{cm}$ 及び $0.04 \mathrm{~mm} / \mathrm{cm}$ 上小さくなった. てれに比べて, シートの雨端部の場合には，反りは前者

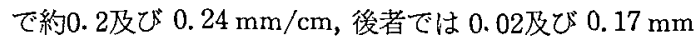
/cm であった. 通常, グリーンシートの内部応力は, 強 制乾燥するほど，またグリーンシートの両端部程大きく なると予想された。しかし，実駼結果は Fig.7 亿みら れる様に，反りは加熱乾燥シートよりむしろ常温乾燥シ ートの方がシート両端部でも大きい，以上の実験より， グリーンシートに残留する内部応力が基板の反りに及ば す影響は小さいと考兄られる。乾燥条件の影響が，グリ ーンシートの両端部で特に大きく現れたのは以下の理由

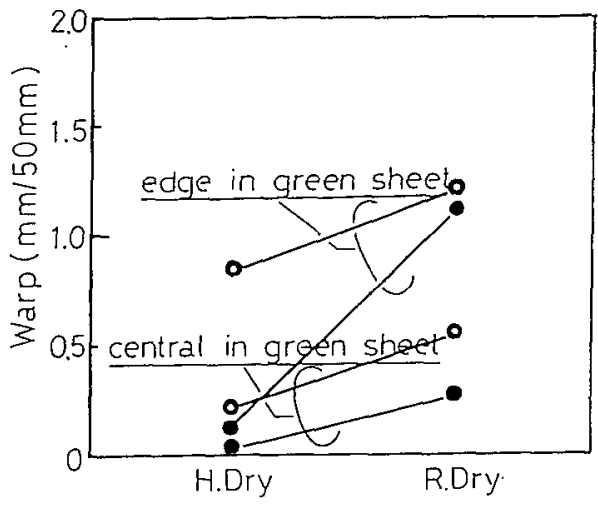

Fig. 7 Warping at the edge and central area in green sheet white circles: green sheet containing the glass flux with a specific surface area of $364 \mathrm{~m}^{2} / \mathrm{g}$ black circles: green sheet containing the glass flux with a specific surface area of $20 \mathrm{~m}^{2} / \mathrm{g}$

$\mathrm{H}$. Dry and R. Dry: drying at $120^{\circ} \mathrm{C}$ and drying at room temperature. 


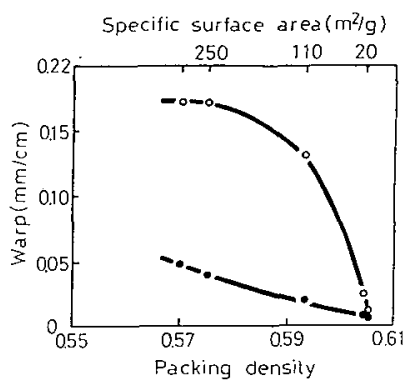

Fig. 8 Warping at the edge and in the central area as a function of packing density. white circles: at the edge area black circles: at the central area.

によると考えられる．すなわち，乾燥によりシートの両 端部に形成された外形枠が乾燥収縮を妨げる. との影響 により, シートの幅方向では粉体充買率に偏りが生じる。 外形枠が形成される原因はグリーンシートが闭端部から 乾燥するためである。一方，加熱乾燥の場合化は，乙の 外形枠はそれ程顕著に影響しない，乙の原因は，スラリ が高温のために低粘度化していること及び外形枠が熱軟 化しているためと考えられる．以上の結果からグリーン シートに残留する内部応力は，基板の反りにそれ程影響 しないと考えられる．そこで，次に粉体充填率と反りの 関係を検討した. Fig. 8 はグリーンシートの粉体充填率 と反りの関保を示した。粉体充埧率は比表面皘が異なる ガラスフラックスを用いるととで変化させた．粉体充冝 率が低いグリーンシート程基板の反りが大きく，またグ リーンシートの両端部程大きくなった．以上の結果より， 基板の反りはグリーンシートの粉体充買率に密接に関係 していることがわかった，そこで，以下の項では粉体充 填率の影響を検討した。

III-3 グリーンシートの粉体充填率と反り

グリーンシートの粉体充填率の厚さ方向の変化を測定 し，反りに及ぼす影響孛検討した． $0.6 \mathrm{~mm}$ 厚さのグリ ーンシートのフィルム面とブレード面をスクレーパで研 削し,フィルム面, 中心層, ブレード面に 3 分割（シー ト厚さは $0.2 \mathrm{~mm}$ ) した.この 3 枚のシート各々のグリ ーン密度を測定した。次にてのシートを $800^{\circ} \mathrm{C}$ で 1 時 間焼成して焼成粉とした，乙の焼成粉の重量を測定し， （1）式により粉体充填率を計算した. Fig. 9 はグリーンシ ートのフィルム面からの距離之, 粉体充潩率の関係を示 した。粉体充填率は，グリーンシートの中心層が高くフ イルム面が最す低かった。フィルム面とブレード面の粉 体充塤率の差は, 加熱乾燥シートの場合には $0.8 \mathrm{vol} \%$ で あった. 一方，常温乾燥の場合には 2 vol\% と 2 倍以上 む大きかった．乙の粉体充埧率差林，Fig. 3 の $\gamma=0.97$ ， $\delta=1.15$ として得られた理論曲線加ら各々焼成収縮率差 に換算すると0.4及び0.9\%である. 従って，反りの原因

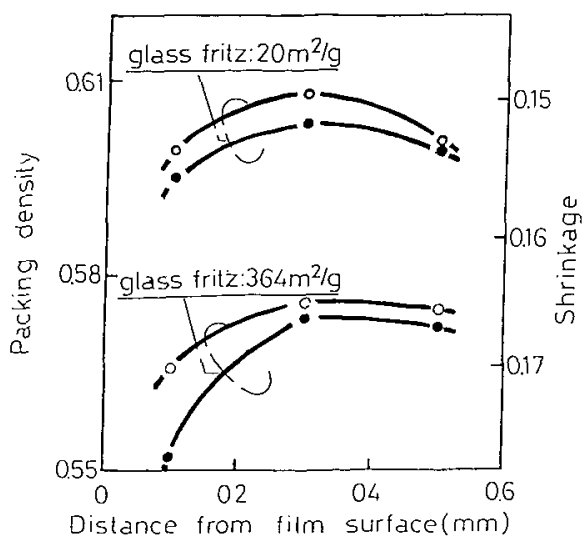

Fig. 9 Packing density as a function of distance from film side surface for a green sheet with a specific surface area of 20 and $364 \mathrm{~m}^{2} / \mathrm{g}$. white circles: drying at $120^{\circ} \mathrm{C}$ black circles: drying at room temperature.

は,グリーンシートの厚さ方向の粉体充填率差にあると 結論できる。また，常温乾燥シートを燒成した時の反り は加熱乾燥シートの場合より大きくなったとと (Fig.7) と良く符合した。フィルム面とブレード面間の粉体充冝 率差は，粉体克填率が低いグリーンシート（此表面積が 大きなガラスフラックスを使用）程大きくなった。これ は粉体充填率が低いシート程，反りが大きくなることで あり Fig. 7, 8 の結果と良く一致した. Fig. 10 は，加熱乾 燥シート（アルミナ含有量； 96\%，ガラスフラックス； 比表面積が $364 \mathrm{~m}^{2} / \mathrm{g}$ の粉体を使用）のフィルム面とブ レード面を研削してから烧成した場合の研削量と反りの 関係を示した. 加熱乾燥シート（比表面積が $364 \mathrm{~m}^{2} / \mathrm{g}$ ) の反りは，そのまま焼成した場合には $0.16 \mathrm{~mm} / \mathrm{cm}(0.8$ $\mathrm{mm} / 50 \mathrm{~mm})$ になった。一方，グリーンシートのフィル ム面を研削したシートの場合には，反りが急激に減少し， 研削量が $0.1 \mathrm{~mm}$ 以上では $0.02 \mathrm{~mm} / \mathrm{cm}$ まで減少した. 一方，ブレード面を研削したシートでは，反りは逆に一

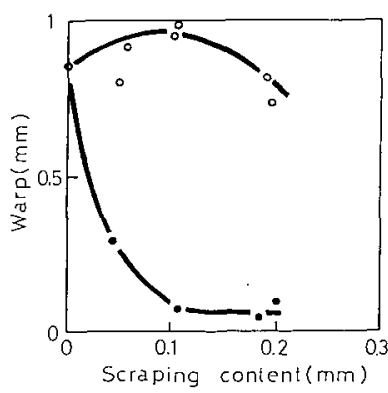

Fig. 10 Warping of sintered substrate vs scraping content from green sheet in the case of sintering after scraping at film and blade side layers in green sheet dried in hot air.

white circles: blade-side layer black circles: film-side layer. 


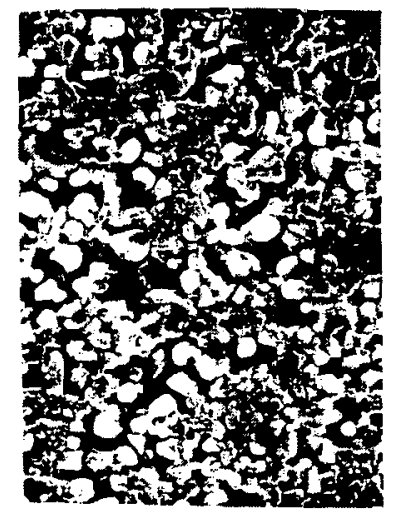

surface on film side

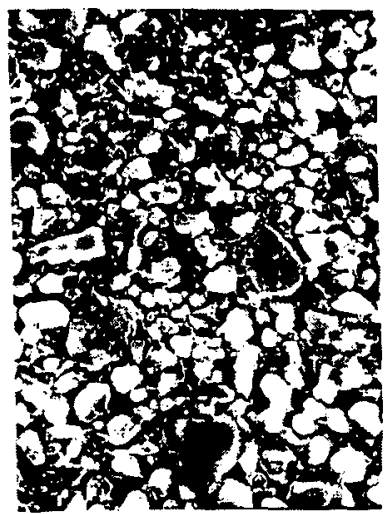

surface on blade side

Fig. 11 SEM photograph of surfaces of the film- and blade-side of green sheet.

度増加した。しかし，研削量が $0.1 \mathrm{~mm}$ 以上になると次 第に小さくなった，以上の結果より，ドクターブレード 成形したグリーンシートは，極く表面近傍，特にフィル 么面近傍力低粉体充填率層になっていると推測された。 そてで，乙れを確かめるために，グリーンシートのフィ ルム面とブレード面の表面を SEM 観察した. Fig.11 は その結果である. 図に示したように，フィルム面がブレ 一ド面に比へて空腙が多く低充垻率層になっていた。 フ ィルム面で粉体充填率が低くなったのは，正-1項で詳述 した原因と同一と考えられる。すなわち，グリーンシー 卜が乾燥収縮する時に，粉体粒子がキャリアフィルムと の間で摩摖応力を受ける. ての応力の影響で粉体精子は 緙密化が妨げられる。一方, ブレード面で粉体充填潭が 低下したのは，以下の理由によると考えられる，乾燥に より形成された外形枠や表面被膜が，ブレード面近傍の 乾燥収縮を妨害する。とのため，X，Y方向の粉体粒子 は緻密化が妨害される．以上の結果より，基板の反りは， グリーンシートの厚み方向の粉体充媜率差が原因之結論 された. 従って, 反りの少ない基板は, 粉体充填率が高 く, 厚さ力向の粉体充填率差が小さいグリーンシートを 燒成すると得られると推定された。ささらに，てのような グリーンシートは, 比表面皘が $20 \mathrm{~m}^{2} / \mathrm{g}$ 以下のフラック スを用い，加熱乾燥すると得られると結論された。

III-3 バインダ量之粉体充填率差, 反りの関係

グリーンシートの厚さ方向の粉体充買率差に及ぼすバ インダ量の影響を検討した．Fig.12 は，グリーンシー ト（バインダ含有量は，無機粉体に対する配合ベースで の重量\%，アルミナ含有量； $96 \%$ ，ガラスフラックス； 比表面積が $20 \mathrm{~m}^{2} / \mathrm{g}$ を使用) のバインダ量とフィルム 面及びブレード面のバインダ含有量差の関係を示した。 図より，含有量差はバインダ量が增加するとともに急激 に隇少した．またバインダ量が18重量\%になったとこ ろで消失した。このバインダ量は粉体精子が 8 配位配列 (単一斜列配位) した（粉体充填摔か $60.45 \mathrm{vol} \%$ ) 場合 に形成される粒子間空淂を完全に埋めるのに必要な量に 相当する，バインダ量が，18重量％より少ない場合にみ

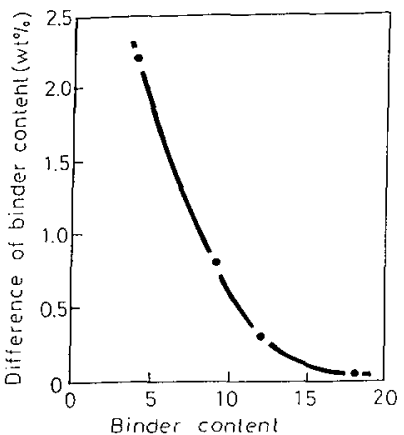

Fig. 12 Difference between binder contents of film- and blade-side layers of the green sheet vs total binder content of the green sheet.

binder content: binder weight $(\mathrm{g})$ in inorganic powder (100 g).

られるフィルム面のバィンダ含有量がブレード面より少 なくなる現象は，以下のように考えると説明できる. 即 ち，スラリ中の溶媒が蒸発すると，その体皘任相当する 空腺がブレード面に形成される。乙の空係に，バインダ 溶波が毛細管現象により，フィルム面から連続的に移行 する.これは，ケミカルサクションカによると考えられ $3^{11,12)}$. 従って, 粉体粒子か作る空隙の体皘 (39.55vol\%) よりむ, バィンダ量が少ない場合には，フィルム面のバ インダ含有量が、ブレード面よりあ少なくなる。しかし， バインダ量が空隙体積に相当する，18重量\%以上では, フィルム面であ粒子間空隙がバインダで埋められる. 徉 って，バインダ含有量差は消失する. Fig. 13 は, バイ ンダ量とグリーンシート(バインダ含有量, アルミ含有量, ガラスフラックスは Fig. 12 と同じ)のフィルム面とブレ 一ド面の粉体充墤率差との関係を示した, 両面間の粉体 充填率差は，バインダ量が増すととあに減少した。そし て，バインダ量が，粉体粒子の作る空隍体積に相当する 量（18重量％）に達した時に零になった。バインダ量が 少なくなったときに，粉体充填率に差が生じるのは以下 


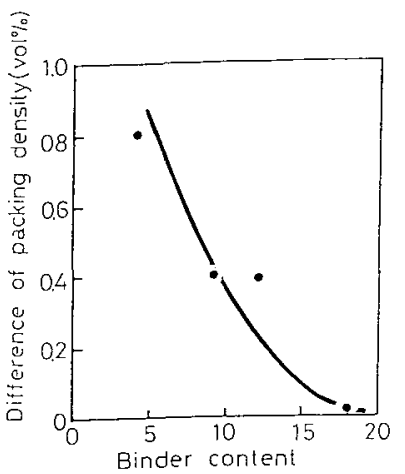

Fig. 13 Difference between packing density of film- and blade-side layers of the green sheet vs total binder content of the green sheet.

binder content: binder weight $(\mathrm{g})$ in inorganic powder $(100 \mathrm{~g})$.

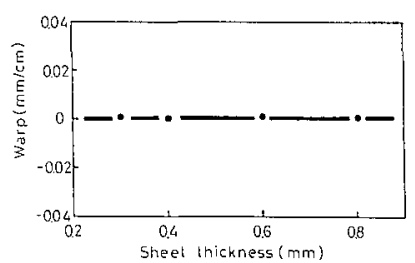

Fig. 14 Warping vs sheet thickness after sintering at $1550^{\circ} \mathrm{C}$, packing density was controlled to 60 to $61 \mathrm{vol} \%$ by the addition of binder of $18 \mathrm{~g}$ weight in inorganic powder of $100 \mathrm{~g}$ weight.

のためと考えられる.スラリ中の粉体粒子は乾燥時にキ ヤリアフィルム面との間で摩擦応力を受ける．この応力 は，先にあ述べたように，粉体粒子が密に詰まろうとす るのを妨害する。一方，グリーンシート中のバインダ含 有量が增加すると, Fig. 12 に示したように，フィルム面 にむバインダが充分満たされるようになる，従ってバイ ンダによる粉体粒子相互を結合する力が強くなる．との カがキャリアフィルムとの間の摩擦応力を越えると粉体 粒子が密に詰まるようになる。従って，フィルム面の 㸮体充填率が高まり，ブレード面との差が消失する. Fig. 14 は, バインダを18重量\%含有したグリーンシート

（アルミナ含有量；96\%，ガラスフラックス；比表面皘 が $20 \mathrm{~m}^{2} / \mathrm{g}$ を使用, 粉体充填率は $60 \sim 61 \mathrm{vol} \%$ ) $1550^{\circ} \mathrm{C}$ で焼成した基板のシート厚さと反りの関係である，図に 示した様に，0.4 mm 以上のグリーンシートの場合，反 りはほとんど生じなかった。ての結果は, 反りの原因が グリーンシートの厚さ方向の粉体充填率差によるとする 本論文の仮説を実証したすのである.

$$
\text { N 結 言 }
$$

アルミナグリーンシートの粉体充填率と焼成基板の収 縮率, 寸法精度, 反りの関係を, 理論的実験的任検討し た.
(1)グリーンシートのX方向のY方向に対する㸁成線収縮 率比は拧よそ0.99である. Z方向の焼成線収縮率は， $\mathrm{X}, \mathrm{Y}$ 方向に比べて小さい.

(2)アルミナ基板の寸法精度は，グリーンシートの燒成収 縮率依存する．乙の焼成收縮率は粉体充填率们直接 依存し，粉体充填率が 1 vol\% 変化する之x方向の寸 法は0.5\%変化する. この值は, 理論計算值とよく一 致した.

(3)グリーンシートを焼成した時に発生する焼結基板の反 りは，アルミナ，フラックスの組成比，粒度分布の異 常によるむのではない. また，グリーンシートの内部 応力は影響していない。

(4)焼結基板の反りは，グリーンシートのZ方向において， $\mathrm{X} ， \mathrm{Y}$ 方向の焼成線収縮率に差があるためである。乙 の焼成線収縮率差が生じるのは,グリーンシートのX， $\mathrm{Y}$ 方向の粉体充填率及びバインダ含有量が Z方向で変 化しているためである.

(5)グリーンシートの粉体充填率は, シート中心層が最も 高く，ブレード面，フィルム面の順に低くなる。

(6) グリーンシートのバインダ含有量は，ブレード面が 最む高く，シート中心層，フィルム面の順に低くなる。 (7)グリーンシートのZ方向の粉体充填率差及びバインダ 含有量差は，粉体充填率を 60 vol\% 以上とし，粉体粒 子が作る空隙の体積に相当するバインダ量を混合する とほ活零になる。

(8) Z方向に括りる粉体充填率差及びバインダ含有量差が ないグリーンシートは，焼成してあ反りを発生しない． (9)粉体充塓率が 60 ～ 61 vol\% のグリーンシートは, 厚さ が $0.4 \mathrm{~mm}$ 以上の場合, 反りを発生しない.

\section{文献}

1) G. J. Hill: Brit. Ceram. Soc., 18 (1970), 262.

2) G. N. Howatt, R. G. Breckenridge and J. M. Brownlow: J. Am. Ceram. Soc., 30 (1947), 237.

3) J. J. Thompson: J. Am. Ceram. Soc. Bull, 42[9] (1963), 480.

4) D. J. Shanefield and R. E. Mistler: J. Am. Ceram. Soc. Bull., 53[5] (1974), 416.

5) S. Ohtomo, M. Kato and K. Korekawa: J. of the Ceram. Soc. of Jpn, 94[2] (1986), 261, in Japanese.

6) T. Ueyama, T. Yamamoto and K. Okazaki: J. of the Jpn. Soc. of Powder and Powder Metallurgy, to be Published.

7) T. Ueyama and Y. Machi: J. of the Jpn Soc. of Powder and Powder Metallurgy, 35[6] (1988), 517, in Japanese.

8) T. Ueyama, H. Wada and N. Kaneko: J. Am. Ceram. Soc., 72[2], (1988), C-74.

9) T. Ueyama and N. Kaneko: Proc, of World Congress of High Tech. Ceram. (1987), 1451.

10) W. O. Smith: Physics, 3[9] (1932), 139.

11) H. Salmang: Silicates Industr., 20[10] (1955), 374.

12) T. Ueyama, H. Wada and H. Uehara: J. of the Jpn. Soc. of Powder and Powder Matellurgy, 35[6] (1988), 526 , in Japanese. 